\title{
Bovine Peritoneum Protection Role on Intestinal Adhesions to a Vascular Graft: A Morphological Analysis
}

\author{
Rol de Protección del Peritoneo Bovino en la Adhesión Intestinal \\ a un Injerto Vascular: Un Análisis Morfológico \\ Rogério Takeyoshi Uema; Valéria Paula Sassoli Fazan; Jesualdo Cherri \& Carlos Eli Piccinato
}

UEMA, T. R.; FAZAN, S. V. P.; CHERRI, J.; PICCINATO, C. E. Bovine peritoneum protection role on intestinal adhesions to a vascular graft: A morphological analysis. Int. J. Morphol., 26(2):269-274, 2008.

SUMMARY: The present study aimed to experimentally evaluate the protection role of glycerin preserved bovine peritoneum (BP) against intestinal adhesions to a vascular graft. Experiments were performed on 24 adult rabbits, randomly dived into two groups. All animals were submitted to a vascular graft over the infra-renal aorta and vena cava. Group I (12 animals) was submitted to a BP patch on the retroperitoneal opening, between the vascular prosthetic graft and the intestinal loops. Group II (12 animals) had the retroperitoneal opening sutured. After 7, 14, 28 and 60 days, 3 animals of each group were randomly killed and the retro peritoneum, with or without the BP patch, was removed for histological analysis. The histological analysis showed that the BP stimulated a moderate to intense inflammatory reaction at the beginning of the experiments and on the 60-day evaluation, the inflammatory reaction was mild, limited to the BP border with its histological structure preserved. In conclusion, the BP is a safe and cheap interposition material to be used between vascular grafts and intestinal loops, presenting a protection role against adhesions between them.

KEY WORDS: Bovine peritoneum; Morphology; Aortoenteric fistula; Vascular graft.

\section{INTRODUCTION}

The occlusive atherosclerotic disease affects most commonly the infrarenal abdominal aorta and the iliac arteries (DeBakey et al., 1985) being one of the most common cause of symptomatic ischemia of the lower limbs (Brewster, 1995). With the introduction of synthetic arterial grafts, by Voorhess et al. (1952), there was an advance on the lower limb ischemia treatment, and the beginning of the implants and/or bypass grafts era (DeBakey et al., 1958; Edwards \& Lyons, 1958). Technological improvement of the grafts material, as well as surgical techniques and intraand post-operation patient care have lead to lower rates of complications.

Special care has to be taken to avoid direct contact with the synthetic vascular graft and the intestinal loops. This can be made by means of a perfect suture of the posterior peritoneum, reducing the incidence of complications such as graft infection, aortoenteric fistula and intestinal adhesions (Kleinman et al., 1979). Deweese \& Fry (1962) described a technique used to prevent aortoenteric fistula occurrence by the interposition of a double peritoneum fold between the duodenum and the aortic graft. Alternatives in substitution of the self-peritoneum were referred by Sproul (1962) and Garrett et al. (1963), using omental transposition to envelope the graft, which was successfully used in an experimental study in dogs, by Goldsmith et al. (1968). Deriu \& Ballota (1982) reported the interposition of a graft piece to avoid erosion, when the use of the large omentum was not possible. Nevertheless, the raise in surgical time and post-operation complications, such as the intestinal obstruction after omental transposition described by Foy et al. (1985), indicating the need to investigate alternative materials for this purpose.

Glycerin preserved bovine peritoneum (BP) as a material for xenografts was described on the late $60 \mathrm{~s}$ (Shusterov et al., 1966; Eliseev, 1967; Eliseev and Pashkova, 1968) and its biocompatibility was tested and approved (Yeliseyev, 1970; Daleck et al., 1992; Costa-Neto et al., 1999). In this way, the aim of the present study is to experimentally evaluate, in rabbits, the possible protection role of glycerin preserved bovine peritoneum (BP) against intestinal adhesions to a vascular graft. 


\section{MATERIAL AND METHOD}

The experimental procedures were performed at the Experimental Surgery Laboratory, School of Medicine of Ribeirão Preto, University of São Paulo. Twenty four female adult New Zealand rabbits, weighing $2000-2300 \mathrm{~g}$ at the beginning of the experiments were randomly dived into two groups. Animals were born and raised in a carefully regulated environment, maintained at 21 to $23^{\circ} \mathrm{C}, 40$ to $70 \%$ relative humidity and 12/12 h light/dark cycle. They were kept in large cages, 3 in each, and received tap water and normal rodent chow ad libitum through the experiment. All procedures were reviewed and approved by the Ethics in animal Research Committee of School of Medicine of Ribeirão Preto, University of São Paulo, SP, Brazil. Every effort was made to minimize the suffering of the animals and to reduce the number of animals used.

All animals were submitted to a vascular graft over the infra-renal aorta and vena cava. Group I (12 animals) were submitted to a BP patch on the retroperitoneal opening, between the vascular prosthetic graft and the intestinal loops. Group II (12 animals) had the retroperitoneal opening sutured.

Surgical procedures. Animals were weighted and submitted to an intramuscular injection of xilazine chloridrate $(10 \mathrm{mg} /$ $\mathrm{Kg}$ ), followed by a thiopental endovenous injection (10mg/ $\mathrm{Kg}$ ). Animals were kept under spontaneous ventilation throughout the procedure. After the laparotomy, the abdominal cavity was explored and the intestinal loops were proximally exteriorized and protected with saline soaked gauze. The retroperitoneum was exposed and cut with a dissecting scissor, from the point of the renal arteries origin, $30 \mathrm{~mm}$ caudal, exposing the abdominal aorta and inferior vena cava. A Dacron graft, knitted type, of $10 \times 10 \mathrm{~mm}$ size was prepared, as was a $12 \times 12 \mathrm{~mm}$ size BP patch. The Dracon graft was placed between the abdominal aorta and inferior vena cava and the intestine, and was sutured, with single stitches of 6-0 polypropylene thread, to the medial border of the psoas major muscle. On Group I animals, the BP patch was positioned between the Dracon graft and the intestinal loops, sutured to the retroperitoneum, also with single stitches of 6-0 polipropilene thread. On Group II animals, the retroperitoneum was sutured continuously with the 6-0 polypropylene thread. Afterwards, the intestine was positioned back to the abdominal cavity ant the anterior abdominal wall was sutured with a 4-0 nylon thread. No drugs were used on the post-operation period.

Tissue removal and macroscopic analysis. After 7, 14, 28 and 60 days, 3 animals of each group were randomly killed, observed macroscopically for the presence of intestinal adhesions and the retroperitoneum with or without the BP was removed for histological analysis. On Group I, the removed tissue consisted of the BP patch, together with self retroperitoneum, including the interface between the graft and the retroperitoneum. On Group II, a piece of $15 \times 15 \mathrm{~mm}$ of the retroperitoneun, including the suture area was removed. Tissue fragments were immersed and fixed in buffered formaldehyde, for at least 48 hours before the histological procedures. The macroscopic study was based on the presence or absence of adhesions between the BP patch and the intestinal loops, according to the following classification: $0=$ absent, $1=$ minimal, removed with delicate dissection, 2 $=$ moderate, removed with aggressive dissection, $3=$ severe, removed only with cutting dissection.

Microscopic study. Tissue fragments were histologically processed with conventional techniques for paraffin embedding, and sections were cut $4 \mu \mathrm{m}$ thick. To investigate the intensity of the inflammatory reaction, sections were stained with hematoxylin-eosin and observed under the oil immersion lens of a light microscope (Axiophot II, Carls Zeiss, Gena, Germany). The intensity of the fibrosis reaction was investigated in sections stained with Masson's thricrome, and observed on the same microscope. The histopathological analysis was performed randomly, by two independent pathologists, with no previous knowledge of the animal group or the other pathologist analysis. The inflammatory and fibrosis intensity was classified using the "cross-system", where $+=$ mild,$++=$ moderate and $+++=$ intense reaction.

Statistical analysis. Mann-Whitney test for independent groups was used for the comparisons between Group I and Group II body weight, on the same experimental group and different experimental times, as also between groups. The Cohen's Kappa coefficient was tested to check the agreement between both pathologists on the analysis of inflammatory and fibrosis reactions. The agreement values used were those proposed by Landis \& Koch (1977). The Fisher's exact test was used to compare the presence of adhesions between Groups I and II. Differences were considered significant when $\mathrm{p}<0.05$.

\section{RESULTS}

None of the animals died during the surgical procedures or during the pos-operation evaluation times. Mean pre-operation body weigh was similar on both groups, with no significant difference between values (Group I = $2033 \pm 29$ and Group II = $2133 \pm 144$ ). The comparisons between body weights on the post-operation times $(7,14$, 

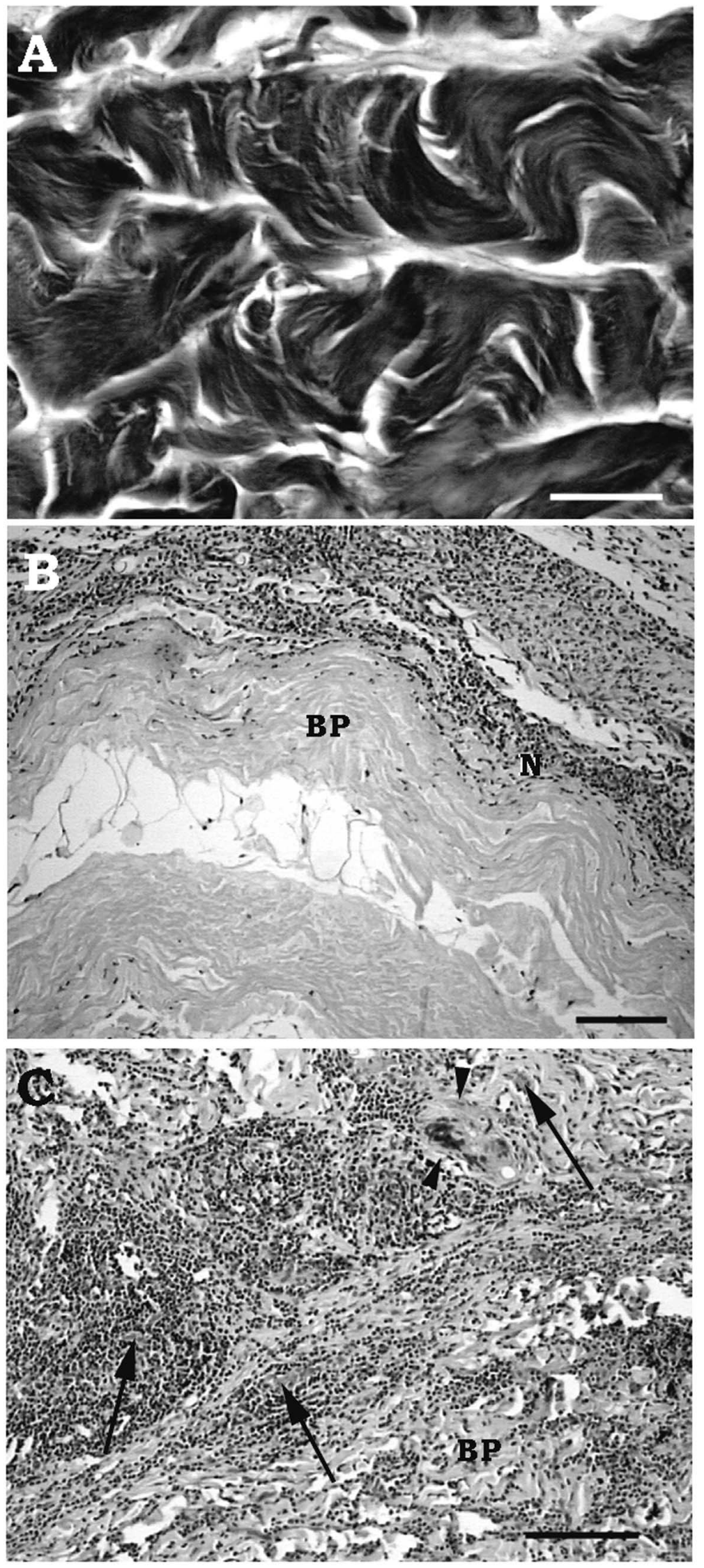

Fig. 1. A Normal histological aspect of the glycerin preserved bovine peritoneum (BP). B: Presence of the BP stimulated a moderate to intense inflammatory reaction characterized, on the $7^{\text {th }}$ day, by the presence of neutrophils $(\mathrm{N})$ on the periphery of the implant. C: On the $14^{\text {th }}$ day, the presence of lymphocytes and foreign body giant cells were identified (arrowheads), indicating the beginning of a chronic inflammatory process. Neovascularization was easily identified (arrows). Hematoxylin-eosin (HE) stained. Bars $=100 \mu \mathrm{m}$.

28 and 60 days) showed a discrete reduction on the $7^{\text {th }}$ day with the animals gaining weight from the $14^{\text {th }}$ to the $60^{\text {th }}$ day. No differences were observed between groups in any experimental time.

On the macroscopic analysis, only one Group I animals showed adhesion between the $\mathrm{BP}$ and the intestine, classified as moderate, with no statistical significance. All BP patches were well preserved, with no signs of necrosis. Also, neovascularization signs could be easily seen.

The Cohen's Kappa coefficient for the analysis between both pathologists of the inflammatory process on Group I was 0.49 and on Group II was 0.57 , both classified as regular/good, and both statistically significant. For all post-operation times studied, a mild inflammatory reaction was identified. On Group I, the presence of the BP stimulated a moderate to intense inflammatory reaction characterized, on the $7^{\text {th }}$ day, by the presence of neutrophils on the periphery of the implant (Fig. 1). On the $14^{\text {th }}$ day, the presence of lymphocytes and foreign body giant cells were identified, indicating the beginning of a chronic inflammatory process. Neovascularization was easily identified (Fig. 1). Nevertheless, polimorphonuclears cells were still present. The main histological characteristic on the $60^{\text {th }}$ day was the presence of calcified areas on the BP and the presence of a light to moderate inflammatory reaction, which was observed on the periphery of the implant, not invasive to the BP. 


\section{DISCUSSION}

Knowledge regarding aortoenteric fistulas came from the beginning of the XIX century, when the first case was described. The total frequency of aortoenteric fistulas varies between 0.5 to $2 \%$ (D'Souza et al., 1987) and Elliott et al. (1974) have found an incidence of $0.7 \%$ after emergency aortic grafts, $1.7 \%$ after aortic aneurysm surgery and $0.2 \%$ after bypass on obstructive pathologies. More than $75 \%$ of aortoenteric fistulas are to the duodenum, $20 \%$ commit the small intestine while large intestine, stomach and other locations are less prevalent (Garrett et al.; Connolly et al., 1981; O'Mara et al., 1981; Grande et al., 1989).

The pathogenesis of the aortoenteric fistula is a controversial issue. Both trauma and infection seem to be the main risk factors. Failure in avoiding the direct contact between the synthetic material and its suture and the intestine has been proposed as the basis of a fistula formation (Deweese \& Fry; Elliott et al.). The importance of the infections in this processes have been evidenced through experimental studies (Humphries et al., 1956; Deweese \& Fry; Busuttil et al., 1979).

Mortality rates of this complication are reported as between 15 and $85 \%$ (Sproul; Kleinman et al.; O'Mara et $a l$.), which is very high and should be avoided. Javid et al. (1962) suggested that a meticulous and safe proximal suture, no lesions of the gastrointestinal tract during the surgical procedure, avoiding contamination of the operative area, and the interposition of a biological tissue between the suture and the duodenum would prevent an aortoenteric fistula. Deweese \& Fry and Elliott et al. related the interposition of a double fold of peritoneum between the graft and the duodenum. But, there are situations when the amount of peritoneum is not sufficient for this technique. In these situations, other techniques were described, like the use of the anterior vertebral fascia (Fry \& Lindenauer, 1967) and the anterior border of the omentum, with a vascularized pedicle (Sproul; Garrett et al.; Goldsmith et al.; Deriu \& Ballota; Foy et al.). Iliopoulus et al. (1983) have described a transmesocolic omentoplasty as a better technique than the previous one, since the transverse colon on its anatomical position allows the omentum to be positioned in parallel to the aorta, being easily interposed between this vessel and the duodenum. Deriu \& Ballotta used a polytetra fluorethylene (PTFE) graft between the duodenum and the vascular graft, with good results, when other tissues were not available for the interposition.

In this way, the present study investigated the possibility of using the $\mathrm{BP}$ as a new interposition material between the aorta and the duodenum, when the peritoneum is not available. The use of BP as an implant material was reported on the late 60's (13-15), and it is being currently used in experimental studies for hernia correction (Yeliseyev; Daleck et al., 1992) and also on orthopedics surgery (CostaNeto et al.).

In the present study, the $\mathrm{PB}$ was preserved on hypertonic glycerin, which has been used for tissue preservation in surgery for years (Leite et al., 1979). Advantages of this procedure are that glycerin does not alter the tensile resistance of biological membranes, it was previously used in the BP conservation in experimental studies (Daleck et al., 1988; Daleck et al., 1992; Costa-Neto et al.) and it has a low cost.

The histological behavior of the BP in the present study was similar to that described previously (Daleck et al., 1988; Costa-Neto et al.) and was characterized by an acute inflammatory reaction in the early stages, limited to the graft border, followed by the presence of lymphocytes and fibroblasts, and vascular neoformation on the $14^{\text {th }}$ day after surgery. The presence of calcification areas on the $60^{\text {th }}$ day suggests the need of further experiments, involving later stages of observation. The BP was easily histologically identified and no destruction, absorption areas or cellular invasion was observed in any of the animals in all experimental groups. Also, no clinical signs that would suggest the graft rejection was observed, suggesting that the BP conserved in glycerin is biocompatible, confirming the histological observations.

Finally, the parietal BP is usually discarded in bovine butchers, making it easy and cheap to obtain. Also, because of its size, a large amount of BP is obtained at once. Glycerin conservation is also a cheap method, collaborating on the reduction of costs of the graft proposed on the present study. In conclusion, the present study suggests that the BP graft is a good interposition material between a vascular graft and the intestinal loops, with a protection role against local adhesions.

\section{ACKNOWLEDGEMENT}

This study was supported by FAPESP (Fundação de Amparo à Pesquisa do Estado de São Paulo, grant numbers: 04/09139-2 and 06/03200-7; and CNPq (Conselho Nacional de Pesquisa e Tecnologia), grant numbers: 303802/20065 (VPSF) and 306452/2006-5 (CEP). 
UEMA, T. R.; FAZAN, S. V. P.; CHERRI, J.; PICCINATO, C. E. Rol de protección del peritoneo Bovino en la adhesión intestinal a un injerto vascular: Un análisis morfológico. Int. J. Morphol., 26(2):269-274, 2008.

RESUMEN: El objetivo de este estudio fue evaluar experimentalmente el rol protector del peritoneo bovino (PB) preservado en la glicerina en contra de las adherencias intestinales de un injerto vascular. Los experimentos se realizaron en 24 conejos adultos, randomizados aleatoriamente en dos grupos. Todos los animales fueron sometidos a un injerto vascular sobre la aorta infra-renal y la vena cava. Grupo I (12 animales), fue sometido a un parche PB en una apertura retroperitoneal suturada, entre el injerto vascular y el intestino. Grupo II (12 animales) con la apertura retroperitoneal suturada. Después de 7, 14, 28 y 60 días, 3 animales de cada grupo fueron sacrificados al azar y el retro peritoneo, con o sin el parche de PB, se retiró para el análisis histológico. El análisis histológico mostró que la PB estimuló una moderada a intensa reacción inflamatoria al inicio de los experimentos y en la evaluación de 60 días, la reacción inflamatoria fue leve, limitada a los bordes de la PB con su estructura histológica preservada. En conclusión, la PB es una forma segura y barata de material de interposición para ser utilizada entre injertos vasculares e intestinales, presentando un rol de protección contra adherencias entre ellos.

PALABRAS CLAVE: Peritoneo bovino; Morfología; Fístula aortoentérica; Injerto vascular.

\section{REFERENCES}

Brewster, D.C. Aortoiliac occlusive disease. In: Yao, J.S.T.; Dean, R.H. \& Brewster, D.C. (Editors), Current diagnosis and treatment in vascular surgery. Norwalk, Appleton \& Lange; 1995.

Busuttil, R.W.; Rees, W.; Baker, J. D. \& Wilson, S. E. Pathogenesis of aortoduodenal fistula: experimental and clinical correlates. Surgery, 85(1):1-13, 1979.

Connolly, J. E.; Kwaan, J. H.; McCart, P. M.; Brownell, D. A. \& Levine, E. F. Aortoenteric fistula. Ann. Surg., 194(4):402-12, 1981.

Costa-Neto, J. M.; Daleck, C. R.; Alessi, A. C. \& Braccialli, C.S. Experimental calcaneal tenoplasty in dogs with bovine peritoneum conserved in glycerol. Cienc. Rural, 29(4):697-703, 1999.

D 'Souza, C. R.; Hebert, R. J.; Trautman, A. F. \& Kilam, S. Aortoenteric fistula: case review and a new surgical technique. Can. J. Surg., 30(6):415-7, 1987.

Daleck, C. R.; Alessi, A. C.; Costa-Neto, J. M.; Daleck, C. L. M. \& Padilha-Filho, J. G. Substitution of a diaphragm flap in dogs with bovine peritoneum conserved in glycerol: an experimental study. Ars. Vet., 4:53-61, 1988.

Daleck, C. R.; Daleck, C. L. M.; Padilha-Filho, J. G. \& Costa-Neto, J. M. Perineal hernia repair in dogs with bovine peritoneum conserved in glycerol. Cienc. Rural, 22: 179183, 1992.

DeBakey, M. E.; Lawrie, G. M. \& Glaeser, D. H. Patterns of athrosclerosis and their surgical significance. Ann. Surg., 201(2):115-31, 1958.
Deriu, G. P. \& Ballota, E. Prevention of enteric erosion by vascular prostheses. Tex. Heart Inst. J., 9(3):325-8, 1982.

Deweese, M. S. \& Fry, W. J. Small-bowel erosion following aortic resection. JAMA, 179: 882-6, 1962.

Edwards, W. S. \& Lyons, C. Three years experience with peripheral arterial grafts of crimped nylon and teflon. Surg. Gynecol. Obstet., 107(1):62-8, 1958.

Eliseev, N. T. Immediate and remote results of the surgical treatment of postoperative ventral hernia with the use of preserved cattle peritoneum. Klin. Khir., 4:65-8, 1967.

Eliseev, N. T. \& Pashkova, L. A. Pathomorphological changes in heterogenic peritoneum in plastic reconstruction of the anterior abdominal wall (experimental study). Klin. Khir., 8:30-4, 1968.

Elliott, J. P. Jr.; Smith, R. F. \& Szilagyi, D. E. Proceedings: Aortoenteric and paraprosthetic-enteric fistulas. Problems of diagnosis and management. Arch. Surg., 108(4):479-90, 1974.

Foy, H.; Fay, S. \& Johansen, K. Bowel obstruction following omental patching of aortic grafts. Am. Surg., 51(11):661$3,1985$.

Fry, W. J. \& Lindenauer, S. M. Infection complicating the use of plastic arterial implants. Arch. Surg., 94:600-9, 1967.

Garrett, H. E.; Beall, A. C. ; Jordan, G. L. \& DeBakey, M. E. Surgical considerations of massive gastrointestinal tract hemorrhage caused by aortoduodenal fistula. Am. J. Surg., 105:6-12, 1963. 
Goldsmith, H.S.; De los Santos, R. \& Beattie, E. J. Jr. Experimental protection of vascular prosthesis by omentum. Arch. Surg., 97(6):872-8, 1968.

Grande, J. P.; Ackermann, D. M. \& Edwards, W. D. Aortoenteric fistulas. A study of 28 autopsied cases spanning 25 years. Arc. Phatol. Lab. Med., 113(11):12715,1989 .

Humphries, A. W.; deWolfe, V. G. \& LeFreve, F. A. Analysis of one hundred twenty consecutive cases of major arterial grafts. JAMA, 161(10):953-6, 1956.

Iliopoulos, J. I.; Pierce, G. E.; Thomas, J. H. \& Hermreck, A. S. Transmesocolic omentoplasty. Surg. Ginecol. Obstet., 157(3):283-4, 1983.

Javid, H.; Julian, O.C.; Dye, W.S. \& Hunter, J.A. Complications of abdominal aortic grafts. Arch. Surg., 85:650-62, 1962.

Kleinman, L. H.; Towne, J. B. \& Bernhard, V. M. A diagnostic and therapeutic approach to aortoenteric fistulas: clinical experience with twenty patients. Surgery, 86(6):868-80, 1979.

Landis, J. R. \& Koch, G.G. An application of hierarchical kappa-type statistics in the assessment of majority agreement among multiple observers. Biometrics, 33(2):636-74, 1977.

Leite, J. B.; Marques, A. F.; Gomes, O. M. \& Pigossi, N. Glycerin and tissue preservation. Rev. Paul. Med., 93:813, 1979.

O`Mara, C. S.; Williams, G. M. \& Ernst, C. B. Secondary aortoenteric fistula. A 20 year experience. Am. J. Surg., 142(2):203-9, 1981.

Shusterov, A. I.; Kolomenskaia, T. A. \& Eliseev, N. T. Surgical treatment of recurrent inguinal hernia using preserved heterogeneous peritoneal tissue. Khirurgiia (Mosk), 42(12):90-4, 1966.

Sproul, G. Rupture of an infected aortic graft into jejunum: resection and survival. JAMA, 182:1118-20, 1962.

Voorhess, A. B. Jr.; Jaretzki, A. 3rd. \& Blakemore, A. H. The use of tubes constructed from vinyon "N" cloth in bridging arterial defects. Ann. Surg., 135(3):332-6, 1952.

Yeliseyev, N. T. Application of preserved heteroperitoneum for plastic operation of postoperational ventral hernia. Acta Chir. Plast., 12(2):77-84, 1970.
Correspondence to:

Valéria Paula Sassoli Fazan, M.D., Ph.D.

Assistant Professor

Departmento de Cirurgia e Anatomia.

Faculdade de Medicina de Ribeirão Preto

Universidade de São Paulo

CEP: $14049-900$

Ribeirão Preto,

São Paulo, BRAZIL

Phone: + 5516 3602-2501

FAX: + $55163633-0017$

Email:vpsfazan@fmrp.usp.br vpsfazan@yahoo.com.br vpsfazan@gmail.com

Received: 20-12-2007

Accepted: 12-02-2008 